Arq. Bras. Med. Vet. Zootec., v.56, n.3, p.398-400, 2004

\title{
Communication
}

[Comunicação]

\section{Reverse transcription-polymerase chain reaction assay for rabies virus detection}

[Protocolo de reação em cadeia pela polimerase precedida de transcrição reversa para a detecção de vírus da raiva]

\author{
J.V. Dantas Junior ${ }^{1}$, L.M.S. Kimura ${ }^{2}$, M.S.R. Ferreira ${ }^{1}$, A.M. Fialho ${ }^{1}$, M.M.S. Almeida ${ }^{1}$, C.R.V. \\ Grégio $^{1}$, P.C. Romijn ${ }^{2}$, J.P.G. Leite ${ }^{1 *}$ \\ ${ }^{1}$ Instituto Oswaldo Cruz \\ Av. Brasil, 4365 \\ 21045-900 - Rio de Janeiro, RJ \\ ${ }^{2}$ Pesagro-Rio
}

Rabies has been reported since antiquity and its economical importance is related to its occurrence in domestic animals, which are source of food. Rabies in herbivorous animals, mainly in cattle, transmitted by bats, represents an important limitation to the development of animal husbandry in Latin America (Constantine, 2003; Belloto, 2001).

The comparison between sequences and segments of different lyssaviruses and among samples of the Pasteur Virus strain (PVS) enabled the identification of preserved regions inside of the Lyssavirus genome, allowing the design of primers able to amplify the viral nucleoprotein, glycoprotein and the pseudogene (Sacramento et al., 1991; Botvinkin et al., 2003).

Based on those acquired knowledge, protocols for lyssaviruses identification in clinical specimens were developed (Sacramento et al., 1991; Botvinkin et al., 2003). Furthermore, phylogenetic analysis of those viruses was performed after amplicons sequencing (Ito et al., 2001; Botvinkin et al., 2003).

Recebido para publicação em 10 de março de 2003 Recebido para publicação, após modificações, em 11 de dezembro de 2003

*Autor para correspondência.

E-mail:.jpgleite@ioc.fiocruz.br
The goal of this study was to establish a reverse transcription-polymerase chain reaction (RTPCR) assay to identify Lyssavirus genus in clinical specimens from different origins, by using primers designed in the nucleoprotein region.

A total of 50 samples of encephalic tissue from animals infected with the rabies virus were used: 44 bovines, 5 equines and 1 chiroptera. Those samples were received from several municipalities of the State of Rio de Janeiro, between January 1999 and June 2001.

The fluorescent-antibody test (FAT) was carried out according to Meslin et al. (1996). Briefly, the imprint of the fragments were incubated with polyclonal anti-rabies fluorescein-labeled immune globulins (Instituto Nacional de Controle de Qualidade em Saúde - INCQS / Fiocruz) and visualized under an immunofluorescent microscope (Zeiss) afterwards.

The intra-cerebral mouse inoculation test (MIT) was conducted according to Meslin et al. (1996). The encephalic tissues were triturated in a mortar, diluted to $10 \%$ in phosphate buffered saline (PBS) pH 7.2, containing penicillin 50IU streptomycin $0.02 \mathrm{mg} / \mathrm{ml}$ and clarified by centrifugation at $900 \mathrm{x} \mathrm{g}$ for five minutes. The supernatant was collected and $0.03 \mathrm{ml}$ of each sample was used to inoculate 21 day-old albino mice by intra-cerebral route. PBS $\mathrm{pH} 7.2$ was used for inoculation as negative control. The 
inoculated animals were observed daily up to 30 days.

The viral RNA was extracted by using TRIzol ${ }^{\mathrm{TM} 1}$ according to the manufacture's recommendations in $10 \%$ of clarified supernatant. The RT-PCR assay was performed as described by Heaton et al. (1997) with modifications. Briefly, $10 \mu \mathrm{l}$ of the extracted RNA was denatured at $75^{\circ} \mathrm{C}$ for 10 minutes, cooled on ice, reverse-transcribed in $40 \mu \mathrm{l}$ of the RT mix: $2 \mu \mathrm{l}$ of $10 \mu \mathrm{M}$ primer JW12 (5' ATGTAACACCC/TCTACAATTG 3' [nt 55-73]), 200U of SuperScript II Reverse Transcriptase, $1 \mathrm{mM}$ of each dATP, dCTP, dTTP, dGTP, 10U of RNAsin, $5 \mu$ of $5 \mathrm{X}$ PCR buffer, $1 \mathrm{mM}$ dithiothreitol and $1,5 \mu \mathrm{l}$ of $50 \mathrm{mM}$ magnesium chloride ${ }^{1}$. The RT mix was incubated for 60 minutes in water bath at $42^{\circ} \mathrm{C}$, boiled for five minutes, and then chilled on ice. Fifty microliters of the amplification mix (PCR) containing $1 \mathrm{mM}$ of each dATP, dCTP, dTTP, dGTP, 2,5U of Taq-Platinum polymerase, $5 \mu \mathrm{l}$ of 10X PCR buffer, $1,5 \mu 1$ of $50 \mathrm{mM}$ magnesium chloride and $4 \mu \mathrm{l}$ of a cocktail of $10 \mu \mathrm{M}$ of the following primers: JW12, JW6 (nt 660-641)(5' CAATTCGCACACATTTTGTG 3' / 5', CAGTTAGCGACATCTTATG 3\% 5, CAGTTGGCACACATCTTGTG 3' $)^{2}$, corresponding to the sequencing of Duvenhage virus, EBLs 1 and 2, and Mokola virus, respectively. After denaturation at $94^{\circ} \mathrm{C}$ for two minutes, the PCR assay consisted of: 40 cycles $\left(94^{\circ} \mathrm{C} / 30 \quad\right.$ seconds, $\quad 45^{\circ} \mathrm{C} / 30$ seconds, $72^{\circ} \mathrm{C} / 60$ seconds), linked by a final extension cycle at $72^{\circ} \mathrm{C} / 7$ minutes. The challenger virus strain (CVS), kindly provided by the INCQS / Fiocruz, Brazil and distilled milli-Q water were used as positive and negative controls, respectively, during all procedures. In order to avoid false-positive results, precautions of manipulation were carried out during the amplification step, as recommended by Kwok and Higuchi (1989).

The RT-PCR amplicons were resolved by electrophoresis on $1.5 \%$ agarose gels ${ }^{1}$, stained with ethidium bromide $(0.5 \mu \mathrm{g} / \mathrm{ml})^{2}$, visualized and photographed by using a polaroid system gel Doc $1000^{2}$. After electrophoresis, a specific 606bp amplicon was observed in all 50 samples

\footnotetext{
${ }^{1}$ All reagents furnished by Invitrogen, Carlsbad, CA, USA ${ }^{2}$ Bio-Rad, Laboratories, USA
}

analyzed, showing a $100 \%$ agreement with the MIT, including one false-negative sample by the FAT from an equine.

The present RT-PCR assay can provide a same day laboratory diagnosis for rabies virus by using different animal species. The results obtained highlighted the potential of the RT-PCR assay as rapid, specific and sensitive tool for the diagnostic investigation of rabies viruses. Despite the excellent results obtained by the MIT and FAT, the RT-PCR has the ability to make a more rapid and definitive diagnosis allowing more directed intervention strategy. Furthermore, RT-PCR assay is useful for the laboratorial diagnosis of rabies viruses from brain tissues from different animal species from different geographic regions. The use of specific primers for the nucleoprotein region of rabies virus and rabies-related viruses increases substantially the possibility of success to detect rabies infection (Heaton et al., 1997).

The future of the amplification techniques lays in their capacity to surpass the sensitivity of the post-mortem diagnostic techniques or in their suitability in diagnosis the infection from live animal secretions. However, diagnostic laboratories are still performing time-consuming and less sensitive techniques (Sacramento et al., 1991). For Kamolvarin et al. (1993) the RT-PCR technique for rabies diagnosis shows important additional advantages compared to the FAT and the MIT: a) it should be used in clinical specimens in bad conditions of conservation (material in decomposition) that often occurs in localities with a tropical climate such as Brazil; b) it is faster than the MIT which often requires an interval of 10 to 30 days for a conclusive result. Our data corroborate with those findings when one clinical specimen (equine 22/06/01) was false-negative by the FAT, but it was identified as positive by the RT-PCR and by the MIT as well, however only 21 days after animal inoculation.

Another importance in routinely using molecular techniques for rabies virus detection is that they allow the implementation of prophylactic and control measures. It also plays an important role in the disease epidemiology once it helps to identify the reservoir in the routine diagnosis (Ito et al., 2001, 2003). 
Recent findings of new bat lyssaviruses throughout the world are showing the importance of molecular methodologies used for diagnosis and for characterization of Lyssavirus genus as well (Botvinkin et al., 2003). Our study, in agreement with previous studies performed in Brazil, shows valuable contribution of molecular analysis methods for rabies virus diagnosis, justifying the implementation of a RT-PCR as a methodology in routine rabies diagnosis in
Brazil. It is concluded that the methodology implemented in this study could be successfully used in the routine diagnosis because it was rapid, specific and showed a high sensitivity, contributing positively for the laboratory diagnosis of rabies virus in tropical countries.

Keywords: rabies virus, reverse transcriptionpolymerase chain reaction, diagnosis

\section{RESUMO}

Este estudo teve por objetivo implantar um protocolo de amplificação genômica, precedida de transcrição reversa (RT-PCR) para o gene da nucleoproteína do vírus da raiva, para a utilização dessa metodologia em laboratórios onde são realizadas investigações para a detecção do vírus rábico. Foram utilizadas 50 amostras de tecido encefálico de animais (44 bovinos, 5 eqüinos e 1 quiróptero) oriundos do Estado do Rio de Janeiro, positivos por imunofluorescência direta elou prova biológica para o vírus rábico. A extração do RNA foi feita a partir da suspensão a 10\% em PBS pH7,2 do tecido encefálico utilizando-se a metodologia de TRIzolTM (Life Technologies) e o protocolo de RT-PCR descrito por Heaton et al. (1997), incluindo algumas modificações. Dentre as 50 amostras analisadas, 50 foram positivas pela prova biológica e pela RT-PCR e destas, 49 foram positivas pela imunofluorescência direta. Estes resultados demonstram ser este protocolo de RT-PCR uma metodologia sensível, especifica, rápida e extremamente valiosa, podendo ser utilizada como rotina em laboratórios que trabalham no diagnóstico de vírus rábico.

Palavras-chave: vírus da raiva, transcrição reversa/reação em cadeia pela polimerase, diagnóstico

\section{ACKNOWLEDGEMENTS}

This work was supported by: PESAGRO, FAPERJ (E26/170.169/2002), IOC and INCQS/Fiocruz, and CNPq. The authors wish to acknowledge Dr. Flavia Barreto for the critical reading of the manuscript.

\section{REFERENCES}

BELOTTO, A.J. Raiva transmitida por morcegos nas Américas: impacto na saúde pública e na produção. In: SEMINÁRIO INTERNACIONAL MORCEGOS, São Paulo. Anais... São Paulo: Memorial da América Latina, 2001. p.25.

BOTVINKIN, A.D.; POLESCHUK, E.M.; KUZMIN, I.V. et al. Novel lyssaviruses isolated from bats in Russia. Emerg. Infect. Dis., v.9, p.1623-1625, 2003.

CONSTANTINE, D. G. Geographic translocation of bats: know and potential problems. Emerg. Infect. Dis., v.9, p.17-21, 2003.

HEATON, P.R.; JOHNSTONE, P.; McELHINNEY, L.M. et al. Heminested PCR assay for detection of six genotypes of rabies and rabies-related viruses. J. Clin. Microbiol., v.35, p.2762-2766, 1997.
ITO, M.; ARAI, T.A.; ITOU, T. et al. Genetic characterization and geographic distribution of rabies virus isolates in Brazil: Identification of two reservoirs, dogs and vampire bats. Virology, v.284, p.214-222, 2001.

ITO, M.; ITOU, T.; SHOJI, Y. et al. Discrimination between dog-related and vampire bat-related rabies viruses in Brazil by strain-specific reverse transcriptasepolymerase chain reaction and restriction fragment length polymorphism analysis. J. Clin. Virol., v.26, p.317-330, 2003.

KAMOLVARIN, N.; TIRAWATNPONG, T.; RATTANASIWAMOKE, $R$. et al. Diagnosis of rabies by polymerase chain reaction with nested primers. $J$. Infect. Dis., v.167, p.207-210, 1993.

KWOK, S.; HIGUCHI, R. Avoiding false positives with PCR. Nature, v.339, p.237-238, 1989.

MESLIN, F.X.; KAPLAN, M.M.; KOPROWSKI, H. Laboratory techniques in rabies. 4.ed. Geneva: WHO, 1996. 476p.

SACRAMENTO, D.; BOURHY, H.; TORDO, N. PCR technique as an alternative method for diagnosis and molecular epidemiology of rabies virus. Molec. Cell. Probes, v.5, p.229-240, 1991. 